\title{
STUDY OF SPIDER DIVERSITY AT CENTRAL ORDNANCE DEPOT (C.O.D.) ESTATE, JABALPUR, MADHYA PRADESH
} SHIVAM DUBEY ${ }^{\mathrm{a}}$, SHIV JI MALVIYA ${ }^{\mathrm{b}}$ AND HEMLATA PANT ${ }^{\mathrm{c}}$

\author{
${ }^{\mathrm{a}}$ Department of Zoology, Govt. Science College, Jabalpur, Madhya Pradesh, India \\ ${ }^{\mathrm{b}}$ Department of Zoology, H.N.B.D. College, Naini, Prayagraj, (U.P.), India \\ ${ }^{c}$ Department of Zoology, C.M.P. P.G. College, Prayagraj, (U.P.), India
}

\begin{abstract}
This study aims to analyse the diversity of spiders (Arachnida: Araneae) at Central Ordnance Depot. The C.O.D. is a defence establishment in the Jabalpur district of Madhya Pradesh. The institute is well known for its lush green surroundings which provide adobe to many species of flora as well as fauna. The area is totally free from access for common people due to high-security reasons, which is a plus point for the spider diversity found here. The current study was performed here by taking field surveys in the accessible regions of the estate. There were 36 species reported belonging to 11 families.
\end{abstract}

KEYWORDS: Araneae, Biodiversity, Jabalpur, Madhya Pradesh

Spiders are usually assessed as generalist hunters and have a great influence on the structure of the community, particularly the food cycle as well as the web. They play a vital role because as a chief insect predator, they keep a check on the insect population (Borror et al., 1996; Kostanjšek et al., 2015). Since spiders can feed on a number of insect species, they are responsible for the diversity control of many insect pests. Thus, it shows that the spider is very important within any food-chain. Similarly, they conjointly play a vital role in agriculture and plantation by safeguarding it from tormentor insects (Brunet, 2000). Moreover, spiders can even be the bioindicator for any alteration in the ecosystem (Kapoor, 2006).

The tropical forest includes a vast diversity of spider species (Suana, 2004). Spider likes to create their net in the places where it can be guarded against direct sunlight. Also, they prefer the spot where they can attach their nets safely from the predators and can get an ample supply of food material, thus decreasing their foraging efforts as well as time (Morse, 1984; Pollard et al., 1995). The spider diversity in any area is affected by many aspects (Larrivee and Buddle, 2010). Any alterations within the current set up can lead to a decrease in their numbers. Similarly, the reduction of floral diversity within the region can lead to a decrease in spider diversity (Samu et al., 1996; Reichert and Lockleyal, 1984). While on the other hand, there are certain factors within an ecosystem that can increase its complexness, which in turn helps in improving the spider populations in the region (Reichert and Lockley, 1984; Chew, 1961).
In order to halt in-progress diversity loss, conservation efforts are typically focussed on crosscountry conservation and diversity action plans, that are dependent upon existing threats to diversity and precise information on the distribution of species within the region (Ceballos and Brown, 1995; Garcia, 2006; Newbold et al., 2009; Arponen, 2012). Deepa et al., (2020). In terms of arthropod conservation, because of the absence of analysis, conservation plans do not generally embrace these species up to the required extent, thus denying their contribution to the general species diversity. This successively results in conservation efforts, that don't effectively cover areas vital for invertebrate diversity (Hernandez-Manrique et al., 2012) and thus most likely end in a dramatically magnified diversity loss among this taxonomic group, and therefore overall species diversity. So as to really check the current trend of diversity loss, it is, therefore, necessary to review patterns of invertebrate diversity a lot intensively and use the obtained insights in updated conservation plans and diversity action plans (Cardoso et al., 2008; Diniz-Filho et al., 2010; Beck et al., 2012; Hernandez-Manrique et al., 2012).

In India, various studies have been conducted on spider diversity. Biologists like Tikader (1970, 1977, 1980, 1982), Patel (1975), Tikader and Biswas (1981), Pocock (1900), and Gajbe and Rane (1992) have contributed a lot in this regard. In the context of Jabalpur, various new species of spiders are described by Gajbe and Gajbe (1999 and 2000) and Bhandari and Gajbe (2001). A similar study was also done by Dubey 
and Pant (2020) in which they have described 48 species of spiders from RDVV Campus, Jabalpur.

\section{MATERIALS AND METHODS}

Sites were selected where there was a higher probability of finding the subjects.

$>$ Three plots of fifty $x$ fifty square centimetres were established in various localities in the study sites.

$>$ The distance among the plots was five hundred meters.

$>$ Then four transects were created in every plot.

$>$ The length of each transaction was kept at fifty meters

$>$ The distance between each transect was kept at fifteen meters.

$>$ The sample is obtained employing a pitfall trap as well as a sweeping net.

$>$ The pitfall trap was to gather spiders that go on the land surface while the sweep net was used to collect the spiders that inhabit the vegetation (Vincent and Hadrien, 2013).

$>$ The spiders that go past the trap is predicted to be cornered and died within.

$>$ There were five traps in one transect with a spacing of fifty meters. The traps ought to be positioned for forty-eight hours (Suana, 2004).

$>$ The sample of spiders was then kept in a tube containing ninety-five percentage of alcohol.

$>$ The collection of spiders from the sweep net is obtained by swinging the net a hundred times in every transect.

$>$ The time of data collection was kept fixed from 09.00 am to 15:00 pm throughout the study period.

$>$ The sampling was conducted for four months.

$>$ The sample taken from the pitfall trap and sweep net was then processed one by one.

$>$ The process of identification is predicated on the external morphology provided within the literature available. Chiefly the literature concerned was Borror et al. (1996), 'Spider and their kin' (Levi and St. Matthew the Apostle, 1990), and therefore the 'Riceland spider of South and Southeast Asia' written by Barrion and Litsinger (1995).

\section{RESULTS}

The results of the surveys of the Central Ordnance Depot (COD), also known as Jabalpur Ordnance Depot, identified altogether 36 species of spider. These species were collected from various localities of the COD Estate. These species belonged to 11 species. The tabular depiction of these species is given in Table 1 which is as follows:
Table 1: Families and Species of spiders identified at COD Estate.

\begin{tabular}{|c|c|c|}
\hline S. No. & Family & Species \\
\hline 1 & Pholcidae & Artema atlanta \\
\hline 2 & Eresidae & Stegodyphus sarasinorum \\
\hline 3 & Hersiliidae & Hersilia savignyi \\
\hline 4 & \multirow{9}{*}{ Araneidae } & Leucauge decorata \\
\hline 5 & & Nephila maculata \\
\hline 6 & & Argiope aemula \\
\hline 7 & & Chorizopes tikaderi \\
\hline 8 & & Cyrtophora cicatrosa \\
\hline 9 & & Cyrtophora citricola \\
\hline 10 & & Cyclosa spirifera \\
\hline 11 & & Larinia bharatae \\
\hline 12 & & Neoscona rumpfi \\
\hline 13 & \multirow{5}{*}{ Lycosidae } & Hippasa pisaurina \\
\hline 14 & & Hippasafabreae \\
\hline 15 & & Arctosa indicus \\
\hline 16 & & Lycosa shaktae \\
\hline 17 & & Hippasa partita \\
\hline 18 & \multirow{2}{*}{ Oxyopidae } & Oxyopes ketani \\
\hline 19 & & Peucetia ashae \\
\hline 20 & Dictynidae & Dictyna shiprae \\
\hline 21 & \multirow{5}{*}{ Gnaphosidae } & Gnaphosa poonaensis \\
\hline 22 & & Callilepis lambai \\
\hline 23 & & Scopodes maitraiae \\
\hline 24 & & Scotophaeus poonaensis \\
\hline 25 & & Poeeiloehroa barmani \\
\hline 26 & \multirow{3}{*}{ Philodromidae } & Philodromus durvei \\
\hline 27 & & Philodromus ashae \\
\hline 28 & & Thanatus ketani \\
\hline 29 & \multirow{7}{*}{ Thomisidae } & Thomisus sundari \\
\hline 30 & & Thomisus rajani \\
\hline 31 & & Runeinia yogeshi \\
\hline 32 & & Oxyptila amkhasensis \\
\hline 33 & & Xystieus bengalensis \\
\hline 34 & & Xystieus bharatae \\
\hline 35 & & Synaema deeorata \\
\hline 36 & Salticidae & Marpissa dhakuriensis \\
\hline
\end{tabular}

The family wise distribution of all the species of spiders is compiled as table 2 the graphical representation of the same is depicted as Figure 1. 
Table 2: Number of species from each family recorded from COD Estate.

\begin{tabular}{|c|c|}
\hline Family & Number of Species \\
\hline Pholcidae & 1 \\
\hline Eresidae & 1 \\
\hline Hersiliidae & 1 \\
\hline Araneidae & 9 \\
\hline Lycosidae & 5 \\
\hline Oxyopidae & 2 \\
\hline Dictynidae & 1 \\
\hline Gnaphosidae & 5 \\
\hline Philodromidae & 3 \\
\hline Thomisidae & 7 \\
\hline Salticidae & 1 \\
\hline Total & 36 \\
\hline
\end{tabular}

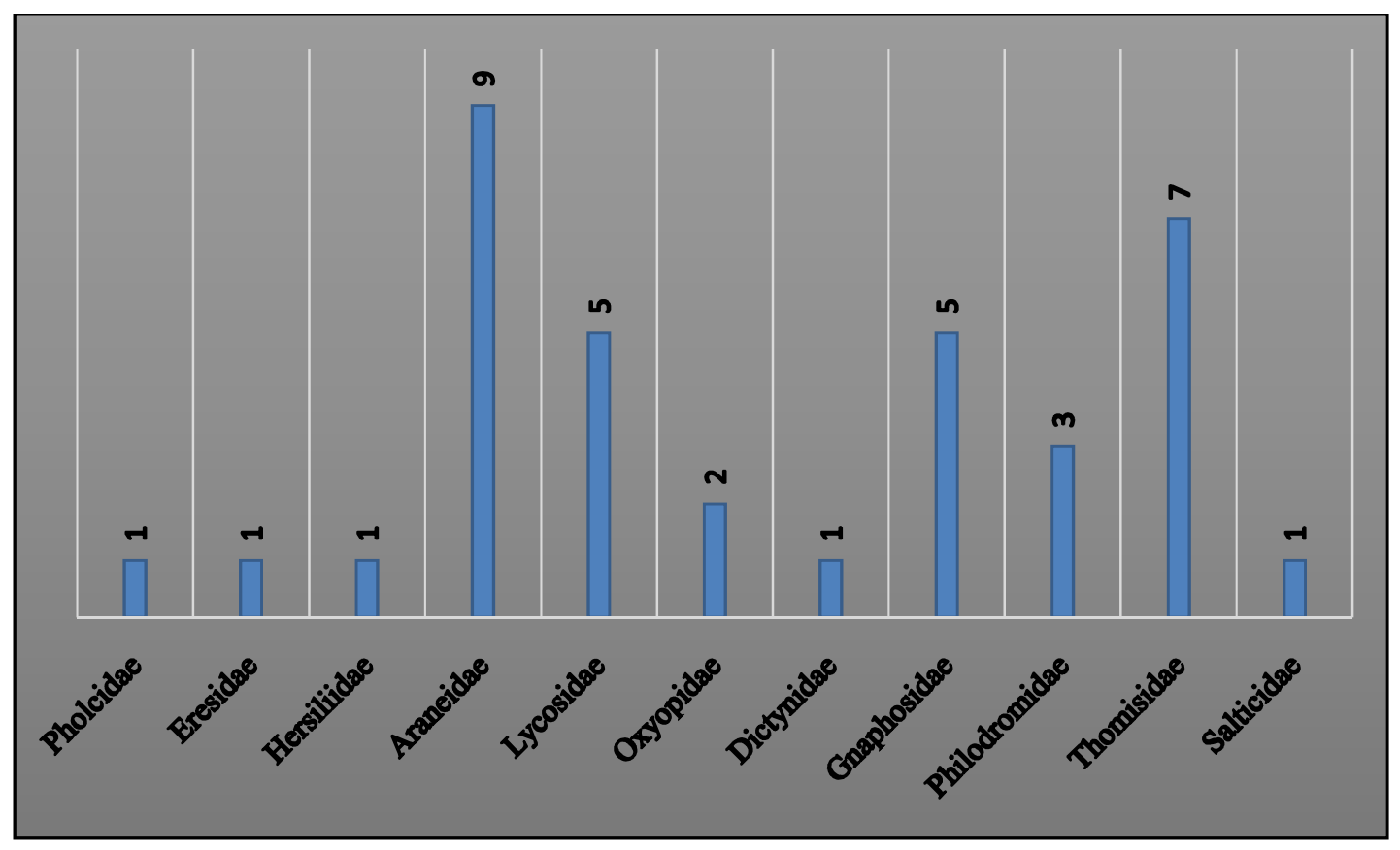

Figure 1: Number of species from each family recorded from COD Estate

\section{DISCUSSION}

A total of 36 species of spiders belonging to 11 families were recorded. The majority of species were from the Araneidae family ( 9 species) followed by Thomisidae (7 species) and Lycosidae and Gnaphosidae (5 species each). While on the other hand, Pholcidae, Eresidae, Hersiliidae, Dictynidae, and Salticidae were the least represented families with one species each. The COD estate is very vast and distributed over 1200 square hectares. A major area is covered with lush green forest and grasslands with can support a diversity of flora as well as fauna. the recorded data of spider diversity shows that area has a very high potential to sustain biodiversity.

\section{ACKNOWLEDGEMENTS}

Authors are grateful to Dr. Rita Bhandari, Prof. and Head, Dept of Zoology, Govt. OFK College, Jabalpur as well as Dr. Sandeep Kushwaha, ZSI for necessary direction and guidance. Authors are also thankful to The President of Uttar Pradesh Higher education Prayagraj, Uttar Pradesh. 


\section{REFERENCES}

Arponen A., 2012. Prioritizing species for conservation planning. Biodivers Conserv., 21:875-893. doi:10.1007/s10531-012-0242-1

Beck J., Ballesteros-Mejia L., Buchmann C.M., Dengler J., Fritz S.A., Gruber B., Hof C., Jansen F., Knapp S., Kreft H., Schneider A.-K., Winter M. and Dormann C.F., 2012. What's on the horizon for macroecology? Ecography, 35(8):673-683. doi:10.1111/j.1600-0587.2012.07364.x

Bhandari R. and Gajbe P., 2001. A study of three new species of spiders of the genera Chorizopes Cambridge, Larinia Simon and Neoseona Simon (Araneae : Araneidae) from M.P., India. Rec. zool. Surv. India, 99(1-4): 59-63.

Bhandari R. and Gajbe P., 2001. Description of four new species of the families Uloboridae, Philodromidae, Gnaphosidae and Lycosidae (Arachnida: Araneae) from M.P., India. Rec. zool. Surv. India, 99(1-4): 87-93.

Bhandari R. and Gajbe P., 2001. Description of three new species of spiders of the genera Tholnisus Walckenaer, Oxyptila Simon and Xysticus Koch (Araneae : Thomisidae) from M.P., India. Rec. zool. Surv. India, 99(1-4): 81-85.

Borror B.J., Triplehorn C.A. and Johnson N.F., 1996. An Introduction to the Study of Insects . $6^{\text {th }}$ edition. Gajah Mada University Press: Yokyakarta, Indonesia.

Brunnet B., 2000. Spider Watch: A guide to Australian Spiders. - Reed New Holland: Sydney.

Cardoso P., Scharff N., Gaspar C., Henriques S.S., Carvalho R., Castro P.H., Schmidt J.B., Silva I., Szu“ts T., De Castro A. and Crespo L.C., 2008. Rapid biodiversity assessment of spiders (Araneae) using semi-quantitative sampling: a case study in a Mediterranean forest. Insect Conserv Divers, 1(2):71-84. doi:10.1111/j.17524598.2007.00008.x

Ceballos G. and Brown J.H., 1995. Global patterns of mammalian diversity, endemism, and endangerment. Conserv Biol., 9(3):559-568. doi:10.1046/j.1523-1739.1995.09030559.x

Chew R.M., 1961. Ecology of spiders of desert community. J. New York Ent. Soc, (9):5-41.

Diniz-Filho J.A.F., De Marco P. Jr. and Hawkins B.A., 2010. Defying the curse of ignorance: perspectives in insect macroecology and conservation biogeography. Insect Conserv Divers, 3(3):172-179. doi:10.1111/j.17524598.2010.00091.x

Dubey S., Malviya S.J. and Pant H., 2020. A Study of Spider Diversity at Rani Durgawati Vishwavidyalaya (RDVV) Campus Jabalpur. Journal of Natural Resource and Development, 15(1) 82-84. ISSN-0974-5033.

Gajbe U.A. and Gajbe P., 1999. A new Cyrtophora spider (Araneae : Araneidae) from Jabalpur, M.P., India. Rec. zoo!. Surv. India, 97(4): 29-31.

Gajbe U.A. and Gajbe P., 1999. A new spcies of the genus Philodromus Walckenaer (Araneae: Philodromidae) from M.P., India. Rec. zoo!. Surv. India, 97(4): 91-93.

Gajbe U.A. and Gajbe P., 1999. A new species of spider of the genus Tibellus Simon from M.P. (Araneae : Philodromidae). Rec. zoo!. Surv. India, 97(3): 191-193.

Gajbe U.A. and Gajbe P., 1999. A new species of spider of the genus Phi!odromus Walckenaer (Araneae : Philodromidae) from M.P., India. Rec. zool. Surv. India, 97(3): 195-197.

Gajbe U.A. and Gajbe P., 1999. A new species of spider of the genus Thanatus Koch (Araneae : Philodromidae) from M.P., India. Rec. zoo!. Surv. India, 97(3): 199-201.

Gajbe U.A. and Gajbe P., 1999. A new species of the genus Pardosa Koch (Araneae : Lycosidae) from M.P., India. Rec. zoo!. Surv. India, 97(4): 95-97.

Gajbe U.A. and Gajbe P., 1999. A new species of the genus Sergio/us Simon from M.P., India (Araneae : Gnaphosidae). Rec. zoo!. Surv. India, 97(4): 99-101.

Gajbe U.A. and Gajbe P., 1999. A new species of the genus Tmarus Simon (Araneae : Thomisidae) from M.P., India. Rec. zoo!. Surv. India, 97(3): 141-143.

Gajbe U.A. and Gajbe P., 1999. On three new species of spiders of the genus Hippasa Simon (Araneae : Lycosidae) from Jabalpur, M.P., India. Rec. zoo!. Surv. India, 97(4): 23-28.

Gajbe U.A. and Gajbe P., 1999. On two new species of spiders of the genus Xysticus Koch (Araneae : Thomisidae) from M.P., India. Rec. zoo!. Surv. India, 97(3): 145-148. 
Gajbe U.A. and Gajbe P., 1999. Two new species of Oxyopes Latreille (Araneae : Oxyopidae) from Jabalpur, M.P. Geobios, 18(1) : 13-16.

Gajbe U.A. and Gajbe P., 1999. Two new species of Peueetia Thorell (Araneae : Oxyopidae) from Jabalpur, M.P. Geobios, 18(1): 9-12.

Gajbe U.A. and Gajbe P., 2000. A new species of spider of the genus ThomisusWalckenaer (Araneae: Thomisidae) from M.P., India. Rec. zoo!. Surv. India, 98(2): 55-57.

Gajbe U.A. and Gajbe P., 2000. A new species of the genus PhilodromusWalckenaer (Araneae : Philodromidae) from M.P., India. Rec. zoo!. Surv. India, 98(2): 51-53.

Gajbe U.A. and Rane P.D., 1992. A new Monaeses spider from Madhya Pradesh, India (Araneae: Thomisidae). Ree. zoo!. Surv. India, 91(3-4): 395-397.

Garcia A., 2006. Using ecological niche modelling to identify diversity hotspots for the herpetofauna of Pacific lowlands and adjacent interior valley of Mexico. Biol Conserv., 130(1): 25-46. doi:10.1016/j.biocon.2005.11.030

Hernandez-Manrique O.L., Numa C., Vverdu' J.R., Galante E. and Lobo J.M., 2012. Current protected sites do not allow the representation of endangered invertebrates: the Spanish case. Insect Conserv Divers, 5(6): 414-421. doi:10.1111/j.1752-4598.2011.00175.x.

Jaiswal D., Chandra K., Kushwaha S. and Gupta D., 2020. Faunal Diversity of Bhoj Wetland: An Overview. In Deepa et al., Faunal Diversity of Bhoj Wetland, Bhopal, Madhya Pradesh, India (A Ramsar Site), Wetland Ecosystem Series, 22: 1-362 (Published by the Director, Zool. Surv. India, Kolkata).

Kapoor V., 2006. An assessment of spider sampling methods in tropical rainforest fragment of the anamalai hills, Western Ghats, India. - Zoo. Print J., 21(12): 2483-2488.

Kostanjšek R., Kuralt Ž., Sivec N. and Velkavrh M., 2015. Comparison of spider diversity in two temperate forests by a rapid survey and its potential in nature conservation studies. - Appl.
Ecol. and Env. Res., 13(3): 693-708. DOI: 10.15666/aeer/1303_693708.

Larrivee M. and Buddle C.M., 2010. Scale dependence of tree trunk spider diversity patterns in vertical and horizontal space. - Ecoscience, 17:400-410.

Morse D.H., 1984. How crab spiders (Araneae: Thomisidae) hunt at flowers. - J of Arach., (12): 307-316.

Newbold T., Gilbert F., Zalat S., El-Gabbas A. and Reader T., 2009. Climate-based models of spatial patterns of species richness in Egypt's butterfly and mammal fauna. J. Biogeogr., 36(11): 2085-2095. doi:10.1111/j.13652699.2009.02140.x

Patel B.H., 1975. Studies on some spiders of Family Argiopidae (Araneae : Arachnida) from Gujarat, India. Vidya, Journ. o/the Univ., 18(1): 153-167.

Pocock R.I., 1900. Fauna of British India, Arachnida. Taylor \& Francis, London, pp. 279.

Pollard S.D., Beck M.W. and Dodson G.N., 1995. Why do male scrab spiders drinks nectar? - Anim. Behav., 49: 1443-1448.

Riechert S.E. and Lockleyal T., 1984. Spiders as biological control agents. - Annu. Rev. of Entomol., (29): 229-320.

Samu F., Sunderland K.D., Topping C.J. and Fenlon J.S., 1996. A spider population in flux: selestion and abandonment of artificial web-sites and the importance of intraspecific interactions in Lepthyphantes tenuis (Aranae: Linyphiidae) in wheat. - Oecologia, 106: 228-239.

Suana I.W., 2004. Bioekology of spiders in ricefield landscape at Cianjur. West Java. Dissertation. School of Post Graduate Studies of Bogor Agricultural University. Bogor, Indonesia, 1-128

Tikader B.K. and Biswas B., 1981. Spider fauna of Calcutta and vicinity. Rec. zool. Surv. India, Occ., 30: 1-148.

Tikader B.K. 1980. Fauna of India, Araneae Spiders. Zool. Surv. India, Vol. I., Kolkata, pp. 447.

Tikader B.K. 1982. Fauna of India, Araneae Spiders. Zool. Surv. India, Vol. II., Kolkata, pp.536. 